\title{
PENGARUH KETINGGIAN TEMPAT DAN LEVEL SANGRAI TERHADAP ATRIBUT MUTU KOPI ARABIKA KABUPATEN BANJARNEGARA
}

\author{
Effect Of Altitude And Roasting Level On Arabic Coffee Quality Attributes In \\ Banjarnegara District
}

\author{
Ali Maksum ${ }^{1}$, Munasib ${ }^{2}$, Ike Sitoresmi Mulyo Purbowati ${ }^{1}$, \\ Ruly Eko Kusuma Kurniawan ${ }^{3}$, dan Furqon ${ }^{4}$ \\ ${ }^{1}$ Laboratorium Pangan dan Gizi, Program Studi Ilmu dan Teknologi Pangan, \\ Fakultas Pertanian, Universitas Jenderal Soedirman \\ ${ }^{2}$ Program Studi Ilmu Gizi, Fakultas Ilmu Kesehatan, Universitas Jenderal Soedirman \\ ${ }^{3}$ Program Studi Pengembangan Sumber Daya Lahan, \\ Fakultas Pertanian,Universitas Jenderal Soedirman \\ ${ }^{4}$ Program Studi Teknik Pertanian, Fakultas Pertanian,Universitas Jenderal Soedirman
}

Alamat korespondensi: ali.maksum@unsoed.ac.id

\begin{abstract}
ABSTRAK
Karakteristik fisikokimia dan atribut sensori kopi arabika dipengaruhi oleh lingkungan tempat tumbuh tanaman kopi dan proses pengolahannya. Tujuan penelitian mencari pengaruh kombinasi lokasi tempat tumbuh tanaman kopi dengan variasi proses sangrai terhadap atribut fisikokimia dan sensori kopi arabika Kabupaten Banjarnegara. Penelitian ini merupakan penelitian eksperimental yang menggunakan metode Rancangan AcakKelompok (RAK) dengan faktorial 2 faktor. Faktor yang diujikan pada penelitian ini adalah: 1) Ketinggian tempat tanaman Kopi dengan taraf: 1000 mdpl (Kecamatan Wanayasa), 1050 (Kecamtan Karangkobar) dan 1100 mdpl (Kecamatan Kalibening). 2) Level sangrai dengan taraf: light dimana kopi disangrai selama 6 menit pada suhu $200^{\circ} \mathrm{C}$, berwarna cokelat cerah. Sangrai level medium dimana kopi disangrai selama 8 menit pada suhu $200^{\circ} \mathrm{C}$, berwarna cokelat. Sangrai level dark dimana kopi disangrai selama 10 menit pada suhu $200^{\circ} \mathrm{C}$, berwarna cokelat kehitaman. Faktor tersebut disusun kedalam rancangan faktorial sehingga diperoleh 9 kombinasi perlakuan. Perlakuan diulang tiga kali sehinggga diperoleh 27 unit percobaan. Pengujian atribut sensoris kopi arabika menggunakan metode analisis mutu skroring pembeda. Hasil penelitian ini adalah level penyangraian berpengaruh terhadap kadar air, $\mathrm{pH}$, total fenol dan aroma sedangakn ketinggian tempat tanaman kopi tidak berpengaruh terhadap kadar air, $\mathrm{pH}$, dan total fenol. Kadar air terendah 2,03\% dan aroma terkuat pada proses sangrai dark, nlai $\mathrm{pH}$ terendah 5,22 dan total fenolik tertinggi 71,4 mg GAE/g pada proses sangarai light.
\end{abstract}

Kata kunci: kopi arabika, sangrai, lokasi, atribut mutu, aroma

\begin{abstract}
The physicochemical characteristics and sensory attributes of arabica coffee are processed by the environment in which the coffee plants grow and their processing. The purpose of this research is to find a combination of the location of coffee plants with a variety of roasting processes on the physicochemical and sensory attributes of Arabica coffee in Banjarnegara Regency. This research is an experimental study using a Randomized Block Design (RBD) method with 2 factors factorial. The factors tested in this study are: 1) The height of the place of coffee plants with levels: 1000 masl (Wanayasa District), 1050 (Karangkobar District) and 1100 masl (Kalibening District). 2) Levels of roasting to a degree: light while coffee is roasted for 6 minutes at $200^{\circ} \mathrm{C}$, light brown. Roast medium level while coffee is roasted for 8 minutes at $200^{\circ} \mathrm{C}$, brown. The level of the roaster is dark while the coffee is roasted for 10 minutes at $200^{\circ} \mathrm{C}$, blackish brown. The factors are arranged based on a factorial design. Obtained 9 combinations of preparation. The treatment was repeated three times so that 27 experimental units were obtained. Testing the sensory attributes of Arabica coffee using a distinguishing scroring quality analysis method. The results of this study are the level of roasting affects the air content, pH, total phenol and aroma while the height of the coffee plant does not increase with air content, $p H$, and total phenol. The lowest air content was $2.03 \%$ and the strongest aroma was in the dark roasting process, the lowest pH was 5.22 and the highest phenolic total was $71.4 \mathrm{mg} \mathrm{GAE} / \mathrm{g}$ in the light sangarai process.
\end{abstract}

Keywords: Arabica coffee, roasted, location, quality attributes, aroma 


\section{PENDAHULUAN}

Badan Pusat Statistik Kabupaten Banjarnegara pada tahun 2018 melaporkan bahwa produksi kopi arabika sebesar 200,55 Ton/tahun dari luas lahan 552,69 Ha. Lahan tanaman kopi arabika berada pada ketinggian 1000 - 1200 mdpl. Variasi ketinggian lokasi tanaman kopi arabika mempengaruhi atribut mutu pada kopi yang menjadi ciri khas yang dihasilkan. Ciri khas tersebut terbentuk karena adaptasi tanaman terhadap stres limgkungan yang berpengaruh terhadap kandungan senyawasenyawa yang terkandung pada biji kopi seperti kafein, antioksidan polifenol, seperti chlorogenic,caffeic, ferulic, dan asam ncoumarik (Fărcaş et al., 2014).

Proses pengolahan juga berpengaruh terhadap atribut mutu kopi arabika selain ketinggian tempat tanaman kopi arabika. Salah satu proses pengolahan yang berpengaruh adalah proses sangrai. Proses sangrai merupakan proses evaporasi air pada biji kopi tanpa menggunakan media minyak. Pada proses sangrai terjadi reaksireaksi seperti reaksi browning nonenzimatis, maillard dan degradasi strecker yang membentuk senyawa-senyawa yang menentukan atribut mutu kopi arabika. Senyawa-senyawa yang terbentuk dari proses roasting merupakan senyawasenyawa penentu atribut mutu sensoris seperti aroma. Atribut sensoris tersebut berasal dari komponen-komponen senyawa seperti asam, alkohol, aldehid, ester, furan, keton, lakton, dan senyawa fenolik (Madihah, 2013; Caporaso et al., 2018).

Merujuk pada hasil penelitan Purnamayanti et al. (2017), menyatakan bahwa suhu penyangraian $235^{\circ} \mathrm{C}$ dengan lama penyangraian 14 menit menghasilkan aroma antara biasa - suka. Selain aroma, proses sangrai berpengaruh terhadap kandungan senyawa fenolik. Rentang proses sangrai semakin lama akan semakin menurunkan senyawa fenolik sebagaimana penelitian Somporn et al. (2011) menyatakan bahawa sangrai light menghasilkan total fenolik sebesar 31,55 mg GAE/g, Diviš et al. (2019) menyatakan total fenolik hasil sangrai medium sebesar 16,7 mg GAE/g. Penurunan kandungan fenol tersebut karena karakteristik senyawa fenolik yang rentan rusak karena panas.

Profil aroma kopi arabika di Provinsi Chiang Rai, Thailand dipengaruhi oleh tinggi tempat tanaman kopi antara $900 \mathrm{dpl}$ dan 1500 dpl serta proses sangrai (Bodner et al., 2019). Hasil penelitian Gamonal et al. (2017) di San Martin, Peru menyatakan bahwa semakin tinggi tempat tanaman kopi diikuti juga peningkatan atribut sensori kopi yang dihasilkan.

Berdasarkan penelitian yang sudah ada, maka terdapat celah penelitian yaitu meneliti atribut mutu kopi arabika dari perbedaan ketinggian tempat tumbuh tanaman kopi pada ketinggian 1000, 1050 
dan 1100 dpl di kabupaten Banjarnegara, Indonesia yang di kombinasikan dengan variasi level proses sangrai. Tujuan penelitian mencari pengaruh tingkat ketinggaian tempat tumbuh tanaman kopi dengan variasi proses sangrai terhadap atribut mutu kopi arabika Kabupaten Banjarnegara.

\section{METODE PENELITIAN}

Alat-alat yang digunakan pada penelitian ini adalah oven MEMMERT 50639551, timbangan analitik AND 14213764, cawan, desikator, labu takar, tabung reaksi, filler, pipet Pyrex, spektrofotometer UV-VIS (UV-1800 240V 206-25400-38), vortex STUART 0895, tabung reaksi, pH meter HANNA, kompor gas, grinder biji kopi, kertas saring, teko, thermometer, alat roasting.
Bahan yang digunakan pada penelitian ini adalah biji kopi arabika (green beans), $\mathrm{CaCO}_{3}$, etanol, $\mathrm{Na}_{2} \mathrm{CO}$, reagen Folin Ciocalteau dan asam galat.

Penentuan Sampel green bean kopi arabika (Coffea arabika) berdasarkan metode surve sequent ketinggian tempat/sampling transeq survey (Rossiter, 2000) diperoleh 3 kecamatan di Kabupaten Banjarnegara dimana tiap kecamatan diwakili satu desa yang memiliki tingkat ketinggian yang berbeda yang memproduksi kopi arabika pada ketinggian 1000 - 1100 mdpl. Ketiga desa tersebut adalah Desa Kubang Kecamatan Wanayasa dengan ketinggian 1000 mdpl, Desa Lekasana Kecamatan Karangkobar dengan ketinggian 1050 mdpl dan Desa Gunung Langit Kecamatan Kalibening dengan ketinggian 1100 mdpl (Gambar 1).

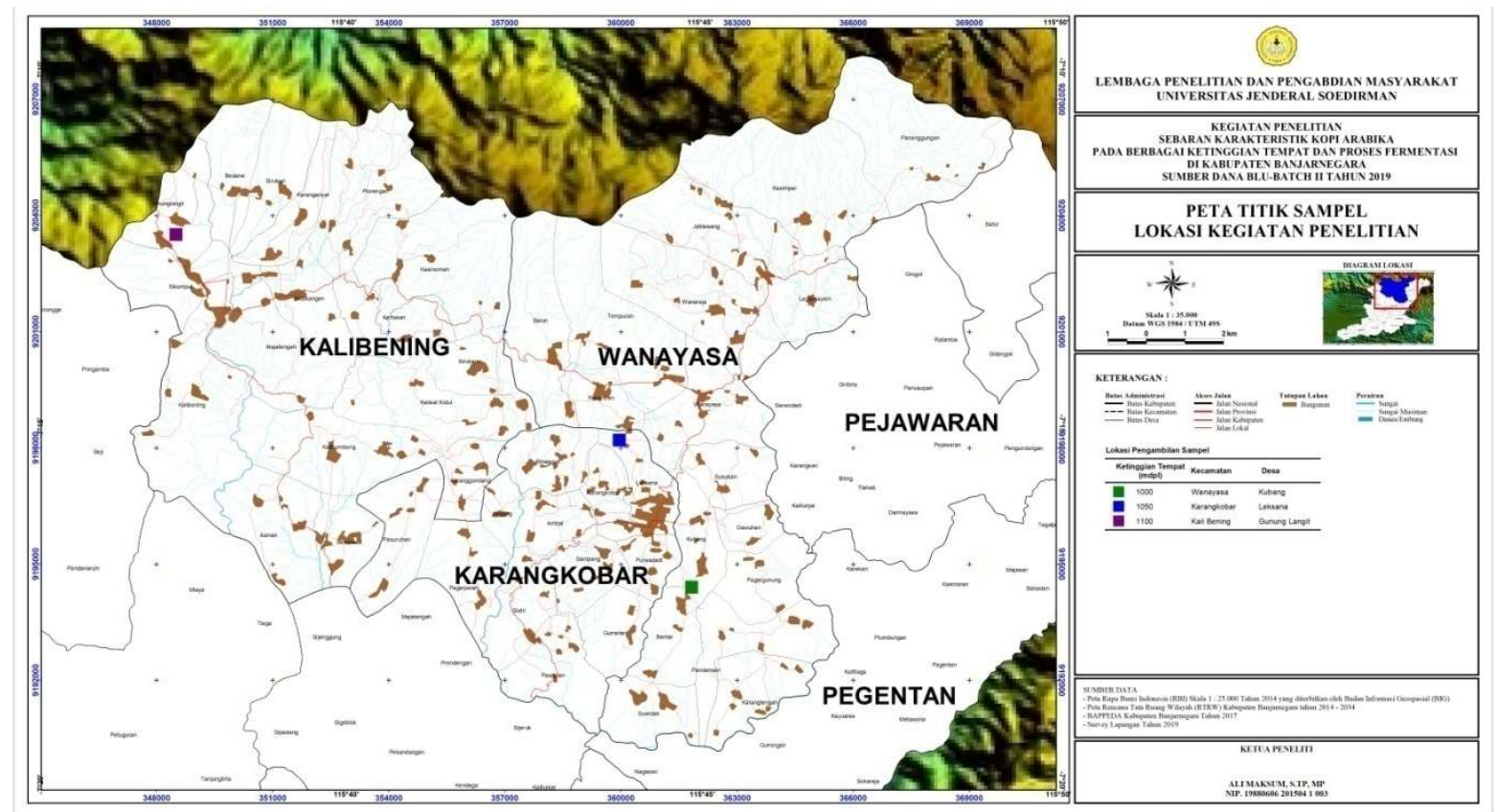

Gambar 1. Peta lokasi pengambilan sampel kopi arabika. 
p-ISSN: 1410-0029; e-ISSN2549-6786

Agrin Vol. 24, No. 1, April 2020

Karakteristik sampel green bean kopi yaitu biji kopi yang telah difermentasi menggunakan metode wet basis, ukuran sedang dan warna biji kehijauan. Sampel kemudian di sangrai pada 3 level yang berbeda yaitu light, medium, dan dark. Sangrai level light dimana kopi disangrai selama 6 menit pada suhu $200^{\circ} \mathrm{C}$, berwarna cokelat cerah. Sangrai level medium dimana kopi disangrai selama 8 menit pada suhu $200^{\circ} \mathrm{C}$, berwarna cokelat. Sangrai level dark dimana kopi disangrai selama 10 menit pada suhu $200^{\circ} \mathrm{C}$, berwarna cokelat kehitaman (Bodner et al., 2019).

Penyajian kopi untuk analisis sensori, kopi diseduh dengan sistem tubruk dimana perbandingan kopi bubuk dengan air yaitu 1:18. Air yang digunakan untuk menyeduh bersuhu $89^{\circ} \mathrm{C}$. Seduhan kopi didiamkan selama 3 menit yang bertujuan untuk ekstraksi kopi (SCAA, 2009).

Analisis parameter yang dilakukan sebagai berikut.

a. Analisis Kadar Air (AOAC, 2000)

Penentuan kadar air dengan menggunakan metode oven. Sampel sebanyak 2 gram ditimbang dan dimasukkan ke dalam cawan yang telah diketahui beratnya, kemudian dikeringkan dalam oven pada suhu $105^{\circ} \mathrm{C}$ selama 4 jam. Setelah itu didinginkan dalam desikator dan ditimbang. Kemudian dipanaskan lagi dalam oven selama 30 menit, didinginkan dalam desikator dan ditimbang. Perlakuan perhitungan sebagai berikut :

$$
K A(\%)=\frac{\text { berat awal }- \text { berat akhir }}{\text { berat akhir }} \times 100 \%
$$

b. $\mathrm{pH}(\mathrm{AOAC}, 2000)$

Pengukuran dilakukan dengan $\mathrm{pH}$ meter. Alat $\mathrm{pH}$ meter dikalibrasi terlebih dulu dengan buffer untuk $\mathrm{pH} 4$ dan $\mathrm{pH}$ 7. Sampel yang dihaluskan diencerkan dengan air panas, kemudian didinginkan. Pisahkan dari endapannya kemudian masukkan ke dalam beaker glass. Alat ph meter dihidupkan, lalu celupkan elektroda ke dalam beaker glass, kemudian putar-putar elektroda larut menjadi homogen. Tunggu sampai angka muncul di alat $\mathrm{pH}$ meter, menunjukkan kadar $\mathrm{pH}$ dari sampel.

c. Analisis Kadar Total Fenol (Purbowati et al., 2018 )

Komponen fenolik (total fenol) diuji menggunakan metode yang dilakukan oleh Purbowati et al. (2018) dengan modifikasi pada pelarutnya yaitu etanol. Asam galat digunakan sebagai standard. Prinsip metode ini terdiri dari menggabungkan $0,1 \mathrm{~mL}$ larutan uji dengan 2,0 mL 2\% $\mathrm{Na}_{2} \mathrm{CO}$. Setelah 2 menit $0,1 \mathrm{~mL} 50 \%$ reagen Folin Ciocalteau ditambahkan dan campuran diinkubasi 30 menit pada suhu kamar. Setelah itu diukur absorbansinya dengan spektrofotometer UV-Vis dengan panjang gelombang $750 \mathrm{~nm}$. 
Kurva standar dibuat dengan mengganti sampel dengan berbagai konsentrasi larutan standar yang sudah dibuat sebelumnya.

d. Analisis Sensori Aroma

Pengujian atribut sensoris aroma kopi arabika menggunakan metode analisis mutu skroring pembeda. Pada metode ini, panelis diminta untuk mengisi skor atribut sensoris yang tertera pada kuisioner. Aroma yaitu $1=$ Sangat lemah, 2= Lemah, 3= Agak kuat, 4= Kuat, 5= Sangat kuat (Nurhayati, 2017). Sampel disajikan dalam cup plastik dengan ukuran yang seragam. Panelis terdiri dari 16 orang panelis semi terlatih dimana minimal panelis semi terlatih 15 orang (Balai Pengkajian Teknologi Pertanian Aceh, 2015).

Penelitian ini merupakan penelitian eksperimental yang menggunakan metode Rancangan Acak Kelompok (RAK) berdasarkan lokasi tempat tumbuh tanaman dengan faktorial 2 faktor. Faktor yang diujikan pada penelitian ini adalah: 1) Ketinggian lokasi tumbuh tanaman kopi dengan taraf: 1000 (A1), 1050 (A2) dan 1100 mdpl (A3). 2) Proses sangrai dengan taraf: light (R1), medium (R2) dan dark (R3). Faktor tersebut disusun kedalam rancangan faktorial sehingga diperoleh 9 kombinasi perlakuan. Perlakuan diulang tiga kali sehinggga diperoleh 27 unit percobaan. Data hasil analis uji kadar air, kadar keasaman, total fenol, dan aroma dianalisis dengan Uji Anova dengan tingkat ketelitian 95\%. Jika terdapat pengaruh signifikan maka dilanjutkan dengan uji Duncan's Multyple Range Test.

\section{HASIL DAN PEMBAHASAN}

\section{Kadar Air}

Berdasarkan hasil penelitian di ketahui bahwa tidak terdapat pengaruh ketinggian tempat tanaman kopi terhadap kadar air. Sedangakan level penyangraian berpengaruh nyata terhadap kadar air. Tidak terdapat interaksi antara ketinggian tempat tanaman kopi dengan level penyangraian terhadap kadar air.

Merujuk pada Gambar 2 diketahui bahwa kadar air level penyangraian light lebih tinggi daripada level penyangraian medium dan dark beruturut-turut yaitu 4,13; 2,22; dan 2,03\% $(\mathrm{P}<0,05)$. Kadar air pada level penyangraian light memiliki kadar air tertinggi karena pada proses penyangraian selama 6 menit sedangkan pada level sangrai medium dan dark selama 8 dan 10 menit. Perubahan kadar air kopi selama proses penyangrain dipengaruhi oleh lamanya waktu penyangraian. Selama proses sangrai terjadi peningkatan volume dan perkembangan pori-pori biji kopi sehingga porositasnya meningkat menyebabkan air keluar dari terpisah secara 
fisik dari biji kopi (Edvan et al., 2016; Wijonarko et al., 2019).

pH

Berdasarkan hasil penelitian di ketahui bahwa tidak terdapat pengaruh ketinggian tempat tanaman kopi terhadap $\mathrm{pH}$. Sedangakan level penyangraian berpengaruh nyata terhadap $\mathrm{pH}$. Merujuk pada Gambar 3 diketahui bahwa terdapat perbedaan nilai $\mathrm{pH}$ pada yang dipengaruhi oleh level penyangraian. Penyangraian level dark mempunyai niali $\mathrm{pH}$ tertinggi diikuti dengan nilai $\mathrm{pH}$ pada level penyangraian medium dan yang terendah adalah level penyangraian light berturut- turut yaitu 5,22; 5,37; dan 5,63 $(\mathrm{P}<0,05)$. Perbedaan nilai $\mathrm{pH}$ terjadi karena adanya penguapan senyawa-senyawa asam seperti asam klorogenat dan asam karboksilat selama proses penyangraian. Senyawasenyawa asam yang mengalami penguapan selama proses sangarai yaitu asam caffeoylquinic, dicaffeoylquinicacids, asam feruloylquinic, dan asam p-coumaroylquinic (Mills et al., 2013). Semakin lama penyangraian maka senyawa-senyawa asam yang teruapkan akan semakin tinggi sehingga menyebakan $\mathrm{pH}$ kopi yang dihasilkan lebih tinggi dibandingkan $\mathrm{pH}$ kopi yang sangrai dengan waktu yang lebih cepat (Fadri et al., 2019; Tian et al., 2018).

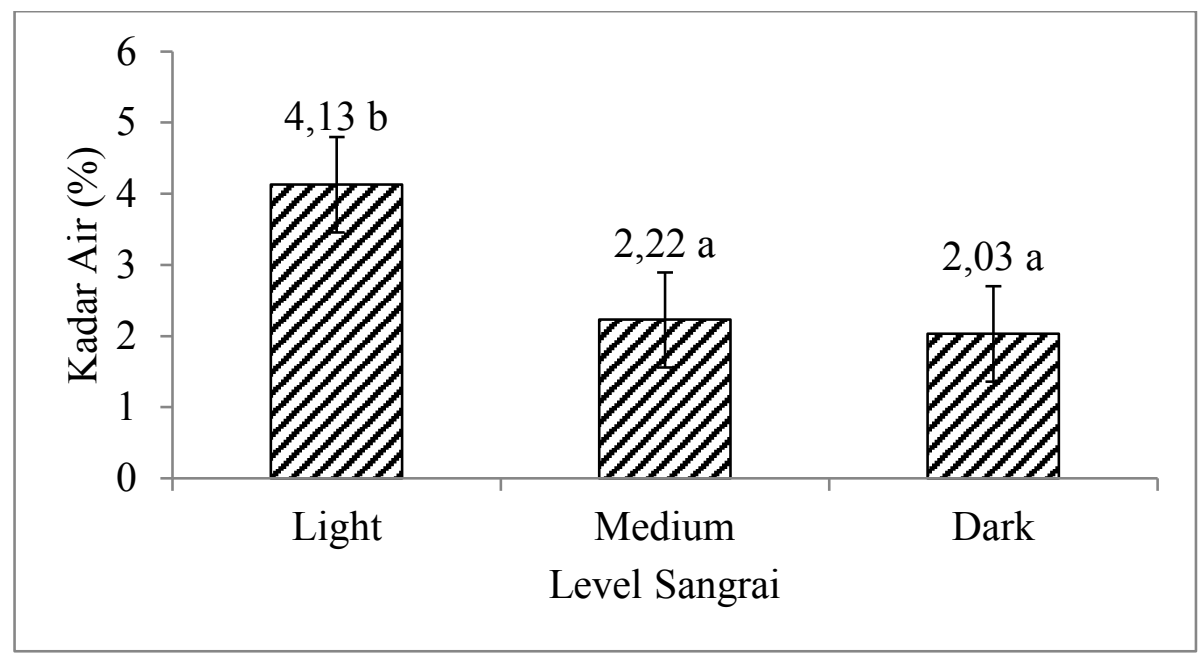

Gambar 2. Pengaruh level sangrai terhadap kadar air kopi arabika. Keterangan: Huruf yang beberbeda pada histogram menunjukkan hasil yang berbeda nyata pada uji Duncan's Multiple Range Test pada tingkata kesalahan $(\alpha) 5 \%$. 


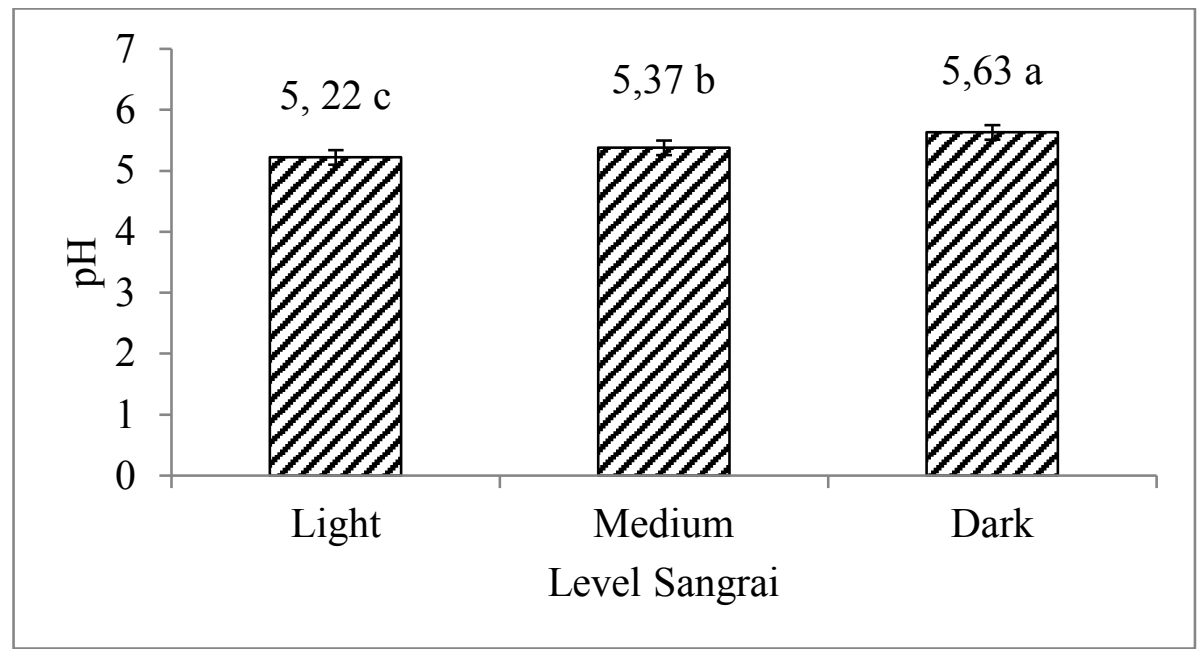

Gambar 3. Pengaruh level sangrai terhadap $\mathrm{pH}$ kopi arabika. Keterangan: Huruf yang beberbeda pada histogram menunjukkan hasil yang berbeda nyata pada uji Duncan's Multiple Range Test pada tingkata kesalahan $(\alpha) 5 \%$.

\section{Total Fenol}

Berdasarkan hasil penelitian di ketahui bahwa tidak terdapat pengaruh ketinggian tempat tanaman kopi terhadap total fenolik. Sedangakan level penyangraian berpengaruh nyata terhadap total fenolik. Tidak terdapat interaksi antara ketinggian tempat tanaman kopi dengan level penyangraian terhadap total fenolik.

Gambar 4. Menunjukkan bahwa kandungan total fenol kopi arabika tertinggi pada level sangarai light diikuti berturutturut medium dan dark yaitu 71,$4 ; 61,8$; dan
61,4 mg GAE/g $(\mathrm{P}<0,05)$. Komponen senyawa fenolik yang pada kopi adalah asam klorogenat, caffeic, ferulic dan pcoumaric (Król, 2019). Hasil penelitian ini sesuai dengan penelitaian Somporn et al. (2011), dimana total fenolik biji kopi sebelum proses roasting 34,32 mg GAE/g, light 31,55 mg GAE/g, medium 24,98 mg GAE/g dan dark 22,31 mg GAE/g. Pemanasan mengakibatkan peningkatan pemutusan ikatatan-ikatan asam-asam fenolik yang berasal dari kerusakan komponen sel.

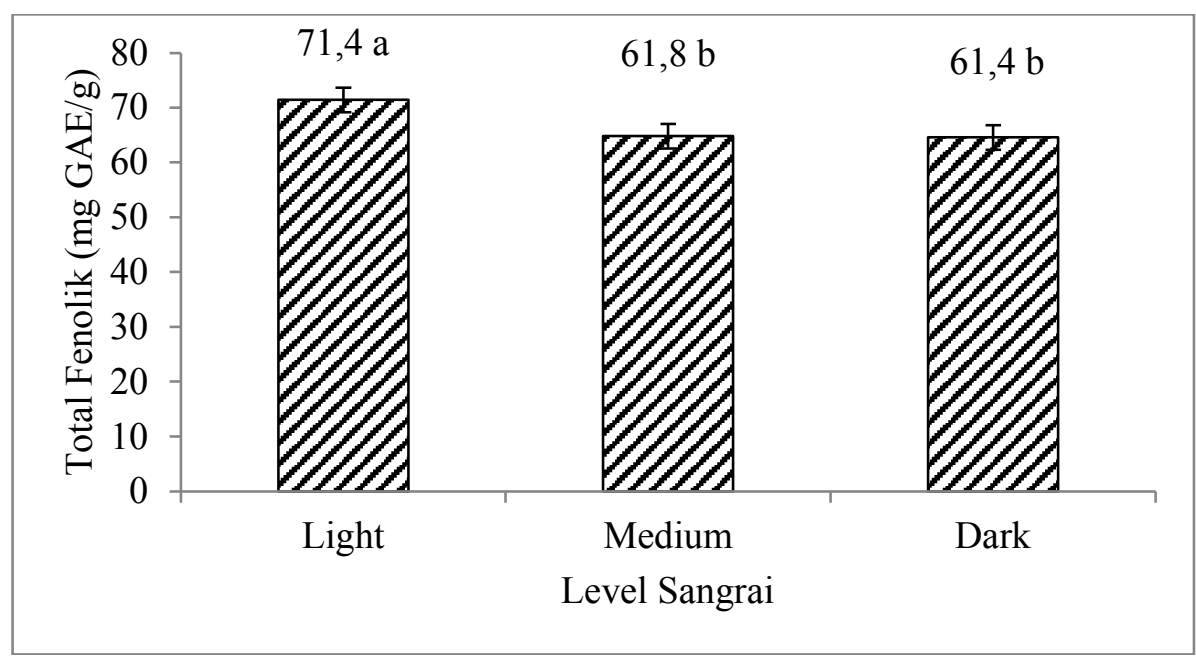


Gambar 4. Pengaruh level sangrai terhadap total fenolik kopi arabika. Keterangan: Huruf yang beberbeda pada histogram menunjukkan hasil yang berbeda nyata pada uji Duncan's Multiple Range Test pada tingkata kesalahan ( $\alpha$ ) 5\%.

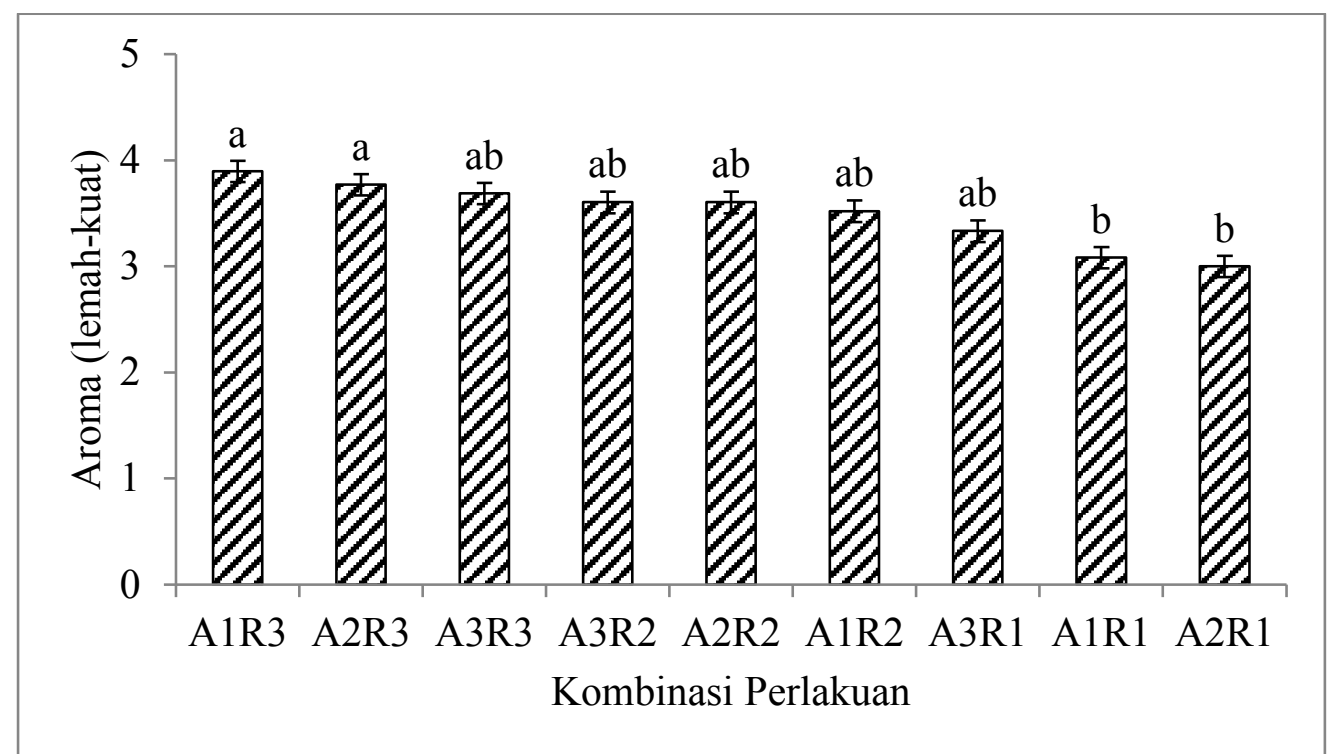

Gambar 5. Hasil uji sensoris aroma kopi arabika. Keterangan: Huruf yang beberbeda pada histogram menunjukkan hasil yang berbeda nyata pada uji Duncan's Multiple Range Test pada tingkata kesalahan ( $\alpha$ ) 5\%. A1R3: Ketinggian 1000 mdpl dengan dark roast; A2R3: Ketinggian 1050 mdpl dengan dark roast; A3R3: Ketinggian 1100 mdpl dengan dark roast; A1R2: Ketinggian 1000 mdpl dengan medium roast; A2R2: Ketinggian 1050 mdpl dengan medium roast; A3R2: Ketinggian 1100 mdpl dengan medium roast; A1R1: Ketinggian 1000 mdpl dengan light roast; A2R1: Ketinggian 1050 mdpl dengan light roast; dan A3R1: Ketinggian 1100 mdpl dengan light roast

\section{Aroma}

Hasil uji sensori atribut Aroma berdasarkan kombinasi tingkat ketinggian tempat tanaman dengan level penyangraian dapat dilihat pada Gambar 5.

Berdasarkan pada Gambar 5 menunjukkan perlakuan kombinasi ketinggian tempat tanaman dengan level penyangraian berpengaruh terhadap atribut sensoris aroma kopi arabika. Perbedaan aroma terjadi pada kombinasi perlakuan yang didasarkan pada level sangrai dark dengan level sangarai light. Aroma level penyangraian dark lebih kuat dibandingkan dengan level penyangraian light. Semakin lama proses penyangraian akan terbentuk senyawa-senyawa volatil yang mempengaruhi aroma kopi. Senyawasenyawa volatil pada kopi yaitu aldehida, keton, alkohol, ester, pirazin, furan, asam, senyawa yang mengandung nitrogen dan senyawa fenolik yang mudah menguap. Senyawa-senyawa volatil terbentuk akibat dari reaksi-reaksi maillard, browning nonenziamtis, degradasi asam amino, degradasi trigonelin, dan degradasi 
senyawa-senyawa fenolik (Caporaso et al., 2018; Fadri et al., 2019; Jokanovića, et al., 2012; Khapre et al., 2017). Schenker et al. (2002) menyatakan bahawa suhu proses sangrai yang dapat menghasilkan aroma original yaitu pada suhu $190-200{ }^{\circ} \mathrm{C}$, jika suhunya sangrai melebihi suhu $230{ }^{\circ} \mathrm{C}$ maka akan terjadi overroasted yang mengakibatkan aroma kopi menjadi tidak terasa.

\section{KESIMPULAN}

Proses penyangraian berpengaruh negatif terhadap kadar air, $\mathrm{pH}$ dan total fenolik serta berpengaruh positif pada aroma. Ketinggian tempat tanaman kopi tidak berpengaruh terhadap kadar air, $\mathrm{pH}$, total fenol dan aroma kopi. Kadar air terendah $2,03 \%$ dan aroma terkuat pada proses sangrai dark, nlai $\mathrm{pH}$ terendah 5,22 dan total fenolik tertinggi 71,4 mg GAE/g pada proses sangarai light.

\section{UCAPAN TERIMA KASIH}

Ucapan trimakasih kami sampaikan kepada LPPM Unsoed yang telah mendanai penilitian ini melalui Skim Riset Dosen Pemula tahun 2019.

\section{DAFTAR PUSTAKA}

AOAC (Association of Official Analytical Chemist ). 2000. Official Methods of Analysis of the AOAC, $16 \mathrm{Ed}$. AOAC.
Badan Pusat Statistik Kabupaten Banjarnegara. 2018. Banjarnegara dalam Angka. BPS.

Balai Pengkajian Teknologi Pertanian Aceh. 2015. Tata Laksan Uji Organoleptik. Balai Pengkajian Teknologi Pertanian Aceh, Banda Aceh.

Bodner, M., K. Morozova, P. Kruathongsri, P. Thakeow, and M. Scampicchio. 2019. Efect of harvesting altitude, fermentation time and roasting degree on the aroma released by cofee powder monitored by proton transfer reaction mass spectrometry. European Food Research and Technology, 245(7): 1499-1506.

Caporaso, N., M. B.Whitworth, C. Cui and I. D.Fiska. 2018. Variability of single bean coffee volatile compounds of Arabica and robusta roasted coffees analysed by SPME-GC-MS. Food Research International, 108: 628640.

Diviš, P., J. Pořízka, and J. Kř́ḱkala. 2019. The effect of coffee beans roasting on its chemical composition. Potravinarstvo Slovak Journal of Food Sciences, 13(1): 344-350.

Edvan, B. T., R. Edison, dan M. Same. 2016. Pengaruh jenis dan lama penyangraian pada mutu kopi robusta (Coffea robusta). Jurnal Agro Industri Perkebunan, 4(1): 31-40.

Fadri, R. A., K. Sayuti, N. Nazir, and I. Suliansyah. 2019. The effect of temperature and roasting duration on physical characteristics and sensory quality of singgalang arabica coffee (Coffea arabica) Agam Regency. Journal of Applied Agricultural Science and Technology, 3(2): 189201.

Fărcaş, A.C., S. A. Socaci, I. Bocăniciu, A. Pop, M. Tofană, S. Muste, and D. Feier. 2014. Evaluation of Biofunctional Compounds Content 
from Brewed Cofee. Bulletin UASVM Food Science and Technology, 71(2): 2344-2344.

Gamonal, L. E., G. Vallejos-Torres, and L. A. López. 2017. Sensory analysis of four cultivars of coffee (Coffea arabica L.), grown at different altitudes in the San Martin region Peru. Ciência Rural, 47(9): 1-5.

Jokanovića, M. R., N. R.Džinića, B. R.Cvetkovićb, S. Grujićc, and B. Odžaković. 2012. Changes of physical properties of coffee beans during roasting. Acta periodica Technologica, 43: 21-31.

Khapre, Y., W. Kyamuhangire, E. K. Njoroge and C. W. Kathurima. 2017. Analysis of the diversity of some arabica and robusta coffee from kenya and uganda by sensory and biochemical components and their correlation to taste. Journal of Environmental Science, Toxicology and Food Technology, 11(10): 39-43.

Król, K, M. Gantner, A. Tatarak and E. Hallmann. 2019. The content of polyphenols in coffee beans as roasting, origin and storage effect. European Food Research and Technology, 246: 33-39.

Madihah, K. Y., A. H. Zaibunnisa, S. Norashikin, O. Rozita, and J. Misnawi. 2013. Optimization of roasting conditions for high-quality Arabica coffee. International Food Research Journal, 20(4): 1623-1627.

Mills, C., M. J. Oruna-Concha, D. S. Mottram, and J. P. E. Spencer. 2013. The effect of processing on chlorogenic acid content of commercially available coffee. Food Chemistry, 141(4): 3335-40.

Nurhayati, N. 2017. Karakteristik sensori kopi celup dan kopi instan varietas robusta dan arabika. Jurnal Ilmiah INOVASI, 17(2): 80-85.
Purbowati, I. S. M., Sujiman, dan A. Maksum. 2018. Aktivitas antibakteri senyawa fenolik ekstrak rosela (Hisbiscus sabdariffa) yang dihasilkan dari beberapa variasi metode dan lama pengeringan. Jurnal Teknologi Industri Pertanian, 28(1): 19-27.

Purnamayanti, N. P. A., I. B. P. Gunadnya, G. Arda. 2017. Pengaruh suhu dan lama penyangraian terhadap karakteristik fisik dan mutu sensori kopi arabika (Coffea arabica L). Jurnal Beta (Biosistem Dan Teknik Pertanian), 5(2): 39-48.

Rossiter, D.G. 2000. Methodology for Soil Resource Inventories. ITC Lecture Notes and Reference. Soil Science Division International Institute for Aerospace Survey and Earth Sciences (ITC).

Schenker, S., C. Heinemann, M. Huber, R. Pompizzi, R. Perren, and R. Escher. 2002. Impact of roasting conditions on the formationof aroma compounds in coffee beans. Journal of Food Science, 67(1): $60-66$.

Somporn, C., A. Kamtuo, P. Theerakulpisut and S. Siriamornpun. 2011. Effects of roasting degree on radical scavenging activity, phenolicsand volatile compounds of Arabica coffee beans (Coffea arabica L.cv.Catimor). International Journal of Food Science and Technology, 46: 2287-2296.

Speciality Coffee Association of America. 2009. SCAA Protocols: Cupping specialty coffee. Speciality Coffee Association of America.

Tian, T., S. Freeman, M. Corey, J. B. German, and D. Barile. 2018. Effect of Roasting on Oligosaccharide Abundance in Arabica Coffee Beans. J. Agric. Food Chem., 66(38): 10067-1007. 
p-ISSN: 1410-0029; e-ISSN2549-6786

Agrin Vol. 24, No. 1, April 2020

Wijonarko, G., Erminawati, dan I.

butter)(pengaruh lama sangrai dan

Handayani. 2019. Sifat kimiawi

lama rendam). Agrin. 23(1): 34-44.

mentega ketapang (Catappa 